\title{
ARTICLE
}

\section{Engineering Ethics from a Justice Perspective: A Critical Repositioning of What It Means To Be an Engineer}

\author{
Caroline Baillie, ${ }^{*}$ Michael Levine ${ }^{+}$ \\ * Faculty of Engineering, Mathematic and Computing, University of Western Australia, \\ caroline.baillie@uwa.edu.au \\ † Philosophy, School of Humanities, University of Western Australia, michael.levine@uwa.edu.au
}

We expect engineers, much as we expect doctors, teachers, plumbers, bankers and even our politicians to be honest. Minimally this means that they should not cheat, falsify documents or reports, keep promises and adhere to contractual obligations. But more can be said about the relation between engineering and ethics. Enlarging what it means to be an engineer is to understand the responsibility of a professional to see beyond what ethics means within the boundaries of contemporary pressures and measures of success, and to know what the available choices are before deciding on any new direction. Some ethical problems are internal to engineering itself. In this paper we use a social justice perspective to critique current ideas about engineering ethics and consider the enlarging which needs to occur to break through the dominant paradigms of the profession.

KEYWORDS: Critical repositioning; ethics; counter hegemony

\section{INTRODUCTION}

There are many who would state that being an ethical engineer is the same as being a just engineer. However, at the recent American Society for Engineering Education annual conference, Jordan discussed "the issue of justice, and how/whether it should be in engineering ethics codes," describing the substantial disagreement amongst members of the Engineering Ethics Division of that Society about this issue (2011, p. 1). In his paper he states that:

\begin{abstract}
Several of us (including the author) supported having a reference to promoting justice in the code, but we had very different personal definitions of justice. To some the term social justice has political implications and implies governmental intervention in many economic areas. To more conservative people (such as this author) social justice means equality of opportunity (not equality of result). We never really did resolve what justice means and that part of the phrase was dropped from our final drafts. Part of this issue is that some see justice as a top down issue which can be implemented largely by governmental action. Others see justice as a bottom up issue best addressed by helping individual poor people to better their lives. (p. 1)
\end{abstract}

There is increasingly an acceptance that ethics is and should be intrinsic to the profession of engineering. However, it is not widely recognized that every engineering decision contains ethical positions. Furthermore, the degree to which there is significant disagreement about what principles, standards (i.e. values) underlay ethical codes should not be minimized; neither should the extent of agreement. Attracted by the precision and exactness of the hard (physical) sciences in general, some engineering professionals attempt to deflect the intrusion of issues of value into 
engineering proper. They eschew the lack of clear and definitive answers associated with philosophy generally and ethics in particular.

In recent years, engineers and many philosophers have argued for and about engineering ethics; but rarely is it acknowledged in these discussions, how the underlying values of the current socioeconomic and cultural context will influence decisions made, and what implications this has for engineering practice. Recently this is being acknowledged more and more, and this paper fits within a new paradigm of engineering ethics, which is based on justice principles. We argue that the values underlying the ethical decision-making process can develop very different responses to the same issue. These values are politically, socially, and culturally determined and in the case of engineering education today, they are often socially constructed and based on current neoliberal (not to be confused with "liberal") dominant discourse. We maintain that ethics based instead on justice (e.g. Rawls, 1971; Sen, 2009) would generate very different "ethical" solutions to given problems.

\section{ENGINEERING AND THE DOMINANT DISCOURSE}

Didier asks a question which he tells us is found in all the introductory texts of engineering ethics in the United States. "Is engineering a profession" (2010, p. 163)? In Engineering and Social Justice, Donna Riley suggests that engineers tend to abdicate responsibility for problem definitions to others, and state instead, as a kind of cover, that they are working on "given" problems. Yet she says, "autonomy and the ability to make independent ethical choices is an essential element of what defines professions in sociological terms. If engineers do not exercise these choices individually and collectively, we may cease to be a profession in at least one important sense" $(2008,110)$. Enlarging what it means to be an engineer is to understand the responsibility of a professional to see beyond what ethics means within the boundaries of contemporary pressures and measures of success, and to know what the available choices are and which among them are morally justifiable before deciding on any new direction. This needs us to move beyond the dominant discourse.

Classical and contemporary social theorists have pointed out-albeit in different ways-that values of the dominant group (a principle force supporting the status quo) are as, or more, powerful than overt coercion in shaping behavior. This is evident in Gramsci's work on hegemony and common sense (1971) and Fleck's thought collectives and thought styles (1979) which refer to the systems of thought (composed of ideas, attitudes, courses of action, beliefs and practices) that systematically construct our understanding of the world in which we live. Fleck argues that stable thought collectives form around organised social groups (such as professional engineers), and "[if] a large group exists long enough, the thought style becomes fixed and formal in structure" (1979, p. 103). He also argues that "the longer a thought has been conveyed within the same thought collective, the more certain it appears" (p. 109). If engineering may be considered a particular community of practice, with an associated common sense and thought style then we maintain that in order to reframe engineering practice, through a lens of justice, a critical repositioning of engineering itself is needed.

Johnson, Lee, and McGregor (1996) explored the notion of "re-engineering" or a "reconceptualisation" of engineering by freeing it from its captive discourses as early as the 90 s. They referred to engineering science and also commerce as two discourses, which have bounded engineering. They also noted that as engineering ethics were located within these discourses, anything which seemed to relate to outside issues were not seen as relevant to the profession. One way forward was seen as the need for a profession that held within it an element of self-reflexivity. We have seen this beginning over the last fifteen years; however, much of the current conversation 
to address this is still located firmly within the dominant neoliberal discourse. New ways of working in industry are framed as "corporate social responsibility."

\section{Counter Hegemonic Engineering Ethics}

There are several different groups working in engineering ethics. Engineers and engineering academics produce the codes of ethics, and write texts and articles drawing on various philosophical theories of ethics (most notably Utilitarianism, Kantian ethics, Virtue theory, ethics of care, etc.). This is supplemented and amplified, often didactically, with case studies of whistleblowers and engineering disasters, in order to engender a sense of responsibility of "duty of care" into engineering students (e.g. Fledderman, 2004; Gorman, Mehalik, \& Werhane, 2000; Martin \& Shinzinger, 2005). Rachel Hollander directs the Center for Engineering, Ethics, and Society, hosted by the US National Academy of Engineering. This is the principal center representing the community of engineering ethicists worldwide. More recently, engineering ethics has formed a community of practice within the domain of Philosophy and Engineering (Bowen, 2010; Coeckelbergh, 2010; Didier, 2010; Luegenbiehl 2010). Facilitated by cofounder David Goldberg, the group's first workshop was held in 2007. Arguably, it has yet to find a functionally adequate blend of engineering and philosophy.

Another group which has emerged, the Engineering, Social Justice and Peace Network (ESJP.org), considers an explicitly "social justice" stance on engineering. As developed over the past eight years, ESJP applies critical social theory to engineering in order to question assumptions of current practice (Catalano, 2006; Kabo \& Baillie, 2009; Riley, 2008). It does so in part by arguing for particular commitments on the part of engineers as well as an awareness of their implications for current practice. There are various ways to do this. Riley, for example, suggests applying what Freire called conscientization (Freire, 2000); the realization that we have choices and can act according to conscience. The question then becomes how we can come to such a realization and act on it outside of our own ways of being and knowing-when and where those are unjustified. How is our conscience to be alerted if it is constructed in terms of our own modes of being and knowing? If we are bounded within a particular thought collective (Fleck, 1979), what becomes common sense and therefore unquestionable and assumed in our place of work, our profession, our society, (Gramsci, 1971) is not visible to us.

Ursula Franklin suggests that choices about engineering projects, processes and products can often be addressed by fine tuning of the language used. Her actual account shows that much more than language modification is involved. She proposes that whenever someone talks about the benefits and costs of a particular engineering project, we should not just focus on "what benefits?" but "whose benefits and whose costs?" (1999, p. 126, emphasis in original). This recommendation is followed up by Riley and others who claim that what is needed is to focus on "macro ethics" (Herkert, 2005) - "the largely ignored body of ethical problems that involve collective action of engineers or society as a whole" (Riley, 2008, p. 110). Presumably this focus would include "big picture" issues like questions of justice and harm. She distinguishes between critical thinking in engineering to critical thinking about engineering. The former is regularly done and accepted by engineering colleagues, while the latter is rarely, if ever. Thus, Franklin's and Riley's recommended "change of focus" involves not only more than fine tuning or a move from the particular to the collective. It involves rethinking the connections between justice, ethics and engineering itself, and more than that, the nature of engineering-what engineering is; what it involves; whom it affects and why and how it affects them. 
Undoubtedly, ESJP has an overtly political posture that many engineering and design professionals will object to. In the latter view, the professional's job is to build and design for clients-not to make political decisions or to (unnecessarily) politicize their projects. This view of engineering as somehow insulated from the politico-ethical sphere is what enlarging the conception of engineering (and the engineer) aims to undermine. ESJP concurs with the claim "that every design and planning decision is a value proposition, and a proposition that has to do with social and political relationships" (Brain, 2005, p. 233). But this includes the decision to limit engagement with questions of ethics and value in their own right, or to not engage with them at all since, like it or not, they are intrinsically involved in such judgments. As Julian Beck, founder of the The Living Theater (New York) once said: "I'm not free until the man who picks my bananas is free" (Beck, 2013).

This political point of departure and the particular use of critical social theory is what differentiates the current work from the increasing number of papers which are written on the subject of ethical engineering. Engineering students are rarely asked to reflect upon what they do, why they do it, and what the implications are within their own culture, let alone in relation to anyone else's. The profession as a whole takes major aspects of dominant discourses for granted-discourse that is intrinsically linked to corresponding ingrained modes of practice and serves to reify such practices. How then can we expect engineering students to learn how to make choices, or to even know that there are choices-many of which are important—to be made?

ESJP adopts many different lenses of social justice to frame their thoughts. In this paper we are using Rawls and Sens considerations of justice. In A Theory of Justice Rawls' presents a detailed account of a conception of justice as fairness-one that he claims rational agents acting in their own self-interest are bound to accept. One direct consequence of his account is that justice as fairness requires a radical redistribution of wealth. The principal tool that Rawls' uses to determine what is fair in terms of justice is to ask what it is that agent would do-the principles they would adopt-in what he terms the original position. It is a thought experiment that Rawls employs to enable us to determine principles of fairness. The original position is a hypothetical situation in which no one knows what particular abilities or knowledge they will have in society or what position (role, job etc) they may occupy. Placed in this hypothetical position-a blind spot with regard to any and all personal circumstances including accidents of birth such as innate intelligence and talents-we are then asked to determine which principles of governance are "just" or fair. Rawls argues for example, that rational self-interested agents in the original position would agree to, among other things, the difference principle.

Amartya Sen, the Nobel prize-winning economist, has suggested that Rawls was too preoccupied with creating a perfectly just society (2009). While this is debatable, the main point of departure with Rawls seems to be that Sen advocates a theory of justice that can serve as the basis of practical reasoning-something he thinks Rawls' account cannot do. He is less concerned with universal principles of liberty and equality than with identifying shared views of injustice in specific situations, and redressing those injustices in culturally specific ways. Sen feels that there is, in European thinking at least, an "analytical disconnect" between how we go about philosophically identifying just and unjust social arrangements, and then how we go about redressing what are perceived to be injustices in any given society. He claims there are crucial inadequacies in concentration on just institutions rather "than on the lives people are able to lead. The focus on actual lives in the assessment of justice has many far-reaching implications for the nature and reach of the idea of justice" (2009, p. xi). "When people across the world agitate to get more global justice," Sen writes, "they are not clamouring for some kind of 'minimal humanitarianism.' They are sensible enough to know that a 'perfectly just' world is a utopian dream. All they want is the 
elimination of some outrageously unjust arrangement to enhance global justice" (p. 26). For Sen, the crucial question is "how can justice be advanced?" (p. 392).

In order to advance fairness and justice in ways (perhaps) acceptable to both Rawls and Sens, the Engineering, Social Justice and Peace network have defined key committments which they believe engineers should adopt in order to be more socially just. In what follows, we use these commitments as a way to examine traditional notions of engineering ethics. In changing the ways engineering ethics is thought about, we propose a new paradigm of engineering professionalism which involves an ethic of responsibility focused on and recognizing the highly contested notion of social justice; one in which engineers know that they must choose, know how to begin to make choices wisely, and know where to go if they cannot. It is a paradigm that sees questions not only of right and wrong, but also of value as at least closely connected with, if not intrinsic to, everyday engineering practice. As a result, the paradigm rejects stereotypical assumptions about what it is to be an engineer and forces us to reconceptualize engineering.

\section{ENGINEERING BASED ON JUSTICE AND FAIRNESS}

The commitments of the ESJP network are as follows: actively working to reduce injustice and enhance equity; working for peace and non-violence; maintaining reflexivity, praxis and the critical voice; and continually reflecting on the network's goals in relation to ethics and social justice. We will take two important focal issues arising from these commitments: balancing diversity and equity; and participatory engagement in engineering.

\section{Addressing Diversity and Equity in Engineering}

Any plausible ethical framework would maintain that diversity and equity, properly understood, must be taken into account when making decisions where these factors are relevant. However, equity in engineering ethics is currently understood simply as "treating equally," rather than equitably, which taken alone could lead to a suppression of diverse ways of being and practicing. This needs to be addressed by showing that different ways of being and knowing must be acknowledged, understood, and taken into account if we are to treat people equitably rather than "equally." A simple definition of equity is given by the Nottingham County Council, UK: "The community we serve is made up of many different people-this is diversity. Yet everyone has the same right to access our services-this is equality of opportunity. Providing those services to individuals in a fair and appropriate way is what we call equity" (2004, p. 1).

Both Rawls' approach and Sen's refinement to justice can be applied directly to engineering cases. Consider, for example, the case of what is fair and equitable in some mining cases. Many mining companies would believe they are working towards a fair and ethical model when they spend money on training programs to assist Indigenous people to work in their mines. It is of course "fair" that we offer jobs to Indigneous people and we educate them accordingly. But an Indigenous person could say that they don't want these jobs because mining desecrates their country and they don't wish to collude with this. The fact that they may nevertheless take the job since they need the money (and why do they need the money?) may exacerbate the Indigenous discomfort. In any case, whether jobs are provided and accepted or not, does little to address the question of whether what the mining companies see as fair and ethical, is just and fair, when considered in the context of, or from the perspective of, the Indigenous people involved. Perhaps the mining company is offering employment by way of coercing an Indigenous community to accept mining on their land. What is just and fair in this case and according to who is it just and fair? Whose values are being presupposed and whose should we work with? If we adopt certain Indigenous ways of knowing, 
then the notion of fairness elicits different answers and outcomes than if we work within a Western paradigm.

Consider an ethical framework that although intended to be innocuous is ethically disturbing. In their classic 2005 US engineering ethics student text Martin and Schinzinger refer to engineering as "social experimentation" and say that "experimentation is commonly recognized as playing an essential role in the design process" (pp. 88-89). They propose that as with drug testing, those who are likely to be affected should give freely informed consent. They discuss the difference between public acceptance of "voluntarily undertaken risks" as in daring sports, while objecting to "involuntary risks" such as living next to a nuclear power plant. They propose that "when it comes to approving nearby oil-drilling platform or a nuclear plant, affected parties expect their consent to be sought no less than it is when a doctor contemplates surgery" (p. 93). But what constitutes free and informed consent in medical procedures-by whom, for whom and under what conditions, etc., may be troublesome; so too may informed consent be problematic for engineering. Some of these problems are identical to or overlap with issues of consent in medical practice, but others may be quite different-particularly in the case of Indigenous communities.

Applying this traditional engineering ethics logic to the above mining case would indicate that informed consent-and they stress that consent must be given without coercion, manipulation or deception-necessarily implies justice. It may do so, if the consent is in fact given under these conditions. However, the problem here is how "coercion," "manipulation," and "deception" are to be understood. What constitutes coercion etc. will typically be different in the mining cases than in the drug testing and other cases they draw comparisons with. Let's look at the case of a remote marginalized community who need money and food. Is their agreement to the development of a new mine on their land (when they do not necessarily understand the implications, even if they are "told,") a free and un-coerced agreement? Is it an "agreement" at all? A non-coerced, nonmanipulative, and non-deceptive agreement may not be possible for those who have been socialized into accepting hand-outs as their traditional means of living. The agency and personal decision making capacity of some Indigenous people may have been gradually eroded by Western urbanization, subjugation and indeed oppression. They are being asked, unjustly on some accounts, to play a game (follow a procedure) which they do not fully understand by means of rules they may not accept. Would any such agreement be based on principles of social justice (for example, on Rawls' account), and if so what are the principles involved?

Working out what fair and appropriate mean, in order to address diversity whilst enabling equality of opportunity, brings with it a messy set of ideas. Two engineering students arrive at University having had very different opportunities, socioeconomic backgrounds, schooling, parenting and cultural conditioning relating to the importance of education. They are given the same exam after the end of term 1. Have they been treated equitably? Ethical codes in engineering are usually based on a very limited and patriarchal set of assumptions about equity. We often hear about "tolerance" for diversity, though this may carry assumptions about what needs to be tolerated, the nature of "objectivity," along with an underlying supposition that there is one way of "knowing" and one "truth." The idea of toleration may imply that there is something or someone "other" to be (merely) tolerated rather than engaged with or accepted as an equal (Brown, 2006). The National Society for Professional Engineers (NSPE) state that "Engineers shall be objective and truthful in professional reports, statements, or testimony" (2007, Article II, Section 3). Communities who see the data differently, i.e. those that have different suppositions that may or may not be justified, or have different data, may not be considered truthful or relevant in this model, and experiential or "subjective" knowledge may be ignored. 


\section{Participatory Engineering}

Understanding diverse people's needs on their own terms is not easy, nor will it happen without issue. Nevertheless, we maintain that this is an important and necessary aspect of engineering ethics, and it is one that implies a newly enlarged notion of engineering as incorporating ethics in relation to justice. However, if engineering products, processes and systems are to reflect the needs of communities and not only those in power (the two are rarely the same), they have to become more participatory. This requires engineering to 1) think ethically from a justice perspective and 2) involve the public in that ethical thinking-about whether, when how and for whom any technological development should take place. It would seem that one way to enhance democracy and social justice through engineering (and other design professions) would be to increase the amounts and kinds of citizen participation that occurs in the design process. After all, a central ethical justification for democracy and democratic decision making is that it ideally allows for the equal consideration of citizens' interests by providing the means to have one's interests heard on a basis of equality with other citizens (cf. Christiano, 2002, p. 32). However, this seemingly innocuous requirement of involving the public is not unproblematic. First of all there are critics who contend that the engineering companies have learnt the language of participation to manipulate it to their own ends. Others are concerned that public participation leads to increased "Nimbyism" (not in my back yard).

Graham describes the differences in the ways in which megaprojects are conducted in the US compared with how they were conducted in Soviet Union and China. The standard argument is that the US projects are increasingly "participatory" with the public; however, he makes it clear that this can lead to a new type of engineer: ". . one who is as skilled at manipulating the public with public relations ... . [as] the old type used to be at manipulating it by claiming superior technical knowledge. . . . In the old days engineers talked of the 'scientific management of recalcitrant workers who tended to loiter on the shop floor'. Today engineers speak of 'managing the public which tends to get obstreperous with large construction projects.' This new type of engineer has learned the language of public hearings, of the courts and of community relations" (1998, p. 122).

Furthermore, it has been shown in cases of urban planning that increased citizen participation has not resulted in better planning-even though it might well be more democratic. To put the matter paradoxically, an increase in the procedural (formal) democratic aspects of planning has often led to a decrease in substantive democratic outcomes in relation to issues of justice and equality. In the case of city planning, for example, "town meetings" and planning sessions are often dominated by special interest groups-developers, financial institutions, architectural firms, and politicians or lobbyists. In short, democratic procedure (increased democratic participation) has often led to considerably worse planning decisions from a democratic or "justice" perspective, than might have occurred with less public input. It has led to decisions that undermine the social agenda that some neighborhood, environmental and design groups seeks to champion. In the case of the New Urbanist movement, Brain pointedly says:

Since the 1960s, the proliferation of public interest and environmental groups ... has given citizens a significant role in land use and planning decisions. At the same time, participation has produced frustration, disillusionment, and cynicism on all sides, encouraging politics that are adversarial ... and frequently a significant obstacle to good planning ... the public process has reinforced some of the most socially and environmentally damaging tendencies of current development patterns while simultaneously undermining faith in government... We have created a regime that almost requires public-spirited citizens to mobilize as narrow-minded, single-issue reactionaries . . . just to ensure that whatever it is doesn't happen in their back yard. (2006, p. 18) 
Nimbyism ("not in my back yard") has become a regular feature of democratic planning in the United States and elsewhere-a predictable result. Thus, New Urbanists and others, who use planning to promote democratic ideals, seem forced to acknowledge that a less democratic, more autocratic (Machiavellian) approach to planning may sometimes be necessary if ideals are to be assured. This will only be the case if those in charge are "enlightened," technically competent authoritarians who know and are capable of pursuing "genuine" democratic ideals-even when the ideals are disputed. Given the history of Machiavellianism in the political sphere, an enlightened public can't help but be suspicious.

There is little question that democratic forms of government do not always deliver the best results for their citizens. Where environmental concerns clash with consumer/constituent interests-this is clearly true. Less democratic forms of government might do better in many cases, and no plausible justification for democracy can be based on the patently false claim that democracy will always or even usually deliver the best overall results for citizens. The justification for democratic forms of government is essentially an ethical one concerning the right to self-determination. So too, increased citizen participation in urban planning has clearly not always resulted in better planning; but it is no part of any justification of New Urbanism or engineering ethics to suppose that wide spread participation of citizens in planning has always been for the better. Engineering ethics, if it is to succeed at all, will have to find ways of helping advance aspirations for democracy and social justice through more inclusive democratic participation and to reconsider what means "better" engineering systems or products-for whom and why.

Whatever setback and however problematic the democratization of planning has been Brain notes there has been considerable success as well:
... "civic environmentalism" has found alternatives to unproductive protest politics or top- down regulation by seeking solutions to complex environmental problems through extensive and substantive cooperation between partners who might otherwise find themselves caught up in an adversarial politics. ... In contrast with simplistic ideas about expanding participation, theorists and activists alike emphasize the importance of a democratic capacity rooted in a pattern of civic association that bridges social differences, constitutes social capital, and provides a necessary civil counterbalance to the bureaucratic state and the effects of global markets. (2006, pp. 18-19)

The move in recent years by city and state governments, like California, to bypass moves by George W. Bush's administration and enact their own tougher environmental standards is interesting here. Democracies are often thought of in nationalistic terms, but there are other levels of constituency driven politics. There need not be limits set on the number and kinds of constituencies (also "communities") a person is invariably a part of. It is the generation and maintenance of the power structures that cause most problems here. This is the first thing which needs to be considered and addressed in considering issues like equity. What is responsible for the generation and maintenance in the first place? How can a code of ethics work to reduce and eliminate these power structures-and is part of the task of such codes to do so? Take the notion of how new engineering knowledge gets created or engineering systems get built. We might desire that this is done in a "participatory way" but not only do we have little guidance in our existing ethical thinking relating to participatory designs and systems, many cases of alleged participatory activity is anything but (see the discussion above). 
Most work related to community participation and technological development, participatory research and the implementation of technology, methods of community organizing in relation to such development, and participatory research and community empowerment, are located in the Global South. However, unlike the case of architecture, planning, and other projects by design professionals in which "participation" and the study of meaningful participation has become de rigueur there appears to be very little evidence of participatory approaches being taken in engineering practice in the North, other than the "managing the public" model described above.

Making an analogy with the Hippocratic Oath analogy: are doctors considered unethical if they make decisions about a patient without consulting the patient? The need for consultation is ingredient in an adequate account of informed consent. Participatory design should be very different from designing something and then asking people if it harms them in some way. Once the technology has been developed it is much harder to "unknow" and to then put the innovation back into the box. Real participatory design will change what gets designed, created and developed from the point of nucleation of the idea. We need to question why we might design something in the first place and ask who it will benefit and who it will cost, before any foundational research takes place.

\section{Critical Reflection and a Way ForWard}

What we are suggesting in the above discussion is that a critically reflective lens to ethical decision making needs to be applied by engineering practitioners in order to promote social justice. This has implications for engineering practice and for engineering education. While it may be possible for someone to think they are being ethical without knowing why they are, and actually to be ethical, it is equally possible for a person to think they are being ethical when they are not-particularly, given the significance of intention in ethics - if they do not understand the implications of their actions. Although thinking critically about their actions will not necessarily cause someone to be just, we maintain it is a necessary part of an ethical education for engineers. In a class on Engineering and Social Justice taught to students of different disciplines at Queens university in Canada, Baillie and Day created an environment which attempted to assist engineers to learn critical thinking. This class demonstrated a key difference between social scientists, on the one hand, and engineers on the other. The former group were extremely able to think critically and to deconstruct any system or technology, from any perspective, but had no idea how to create new knowledge or build ideas as alternatives. Engineers were the contrary (Kabo \& Baillie, 2009). Combining these skills would provide a perfect opportunity to deconstruct and build a new approach to engineering for a just society. Asking students to deconstruct an existing technology from a socially just perspective, and then to think of alternatives to address the aspects they had questioned, could be an exercise in any design class.

In so far as we would like to encourage engineering students to critically reflect, we have precious few examples to show them of engineers doing so in practice. In an attempt to develop an engineering practice, motivated by principles of justice, and to provide a case for continual self reflection and critique, where theory could be tested against practice, one of the authors, Baillie, founded Waste for Life (wasteforlife.org) in 2006. The informal network is based on her research on upcycling waste to create strong "composite" products of waste plastic and fibre. The informal recovery of materials from waste is known to be an important survival strategy for marginalized groups in developing countries to become autonomous. Waste for Life was born of the potential for waste scavengers to move directly to market, by recycling and creating their own products to sell. Waste for Life was born of the need to find real examples of ethical, just engineering: whose purpose was to explicitly reduce injustice in the world. A self-reflective critique of Waste for Life has appeared in Engineering and Social Justice: In the University and Beyond (Baillie, 2012) 
demonstrating the difficulties and yet potential of practicing engineering in this counter hegemonic manner.

\section{SUMMARY THOUGHTS}

No one is questioning that engineering needs ethics. But every ethical code is enacted within the particular hegemonic value system in which it is created. Even if the words are the same on the ethical code, the way they are interpreted within a particular socioeconomic and cultural context will determine what is seen to be ethical. The way that ethics or ethical codes are understood and used in engineering or any other profession will always reflect the dominant discourse. To resist aspects which are unethical we must go deeper to uncover forms of existing and accepted practices which are unethical. Critically incorporating a Rawlsian/Sen definition of justice and fairness is one way forward.

\section{REFERENCES}

Baillie, C. (2012). Waste for life: Socially just materials research. In C. Baillie, A. L. Pawley, \& D. Riley (Eds.), Engineering and social justice: In the university and beyond (pp. 87-106). West Lafayette, IN: Purdue University Press.

Beck, J., Living theatre (2013) http://en.wikipedia.org/wiki/The Living_Theatre

Bowen, W. R. (2010). Prioritising people: Outline of an aspirational engineering ethic. In I. Van de Poel \& D. E. Goldberg (Eds.), Philosophy and engineering: An emerging agenda (pp. 135-146). New York, NY: Springer.

Brain, D. (2005). From good neighborhoods to sustainable cities: Social science and the social agenda of the new urbanism. International Regional Science Review, 28(2), 217-238.

Brain, D. (2006). Democracy and urban design: The transect as civic renewal. Places, 18(1), 18-23.

Brown, W. (2006). Regulating aversion. Princeton, NJ: Princeton University Press.

Catalano, G. (2006). Engineering ethics: Peace, justice and the earth. San Rafael, CA: Morgan \& Claypool. doi:10.2200/S00039ED1V01Y200606ETS001

Christiano, T. (2002). Democracy as equality. In Estlund, D. (Ed.), Democracy (pp. 31-50). Malden, MA: Blackwell.

Coeckelbergh, M. (2010). Imagining worlds: Responsible engineering under conditions of epistemic opacity. In I. Van de Poel \& D. E. Goldberg (Eds.), Philosophy and engineering: An emerging agenda (pp. 175-188). New York, NY: Springer.

Didier, C. (2010). Professional ethics without the profession: A French view of engineering ethics. In I. Van de Poel \& D. E. Goldberg (Eds.), Philosophy and engineering: An emerging agenda (pp. 161-174). New York, NY: Springer.

Fleck, L. (1979). Genesis and development of a scientific fact. Chicago, IL: University of Chicago Press.

Fledderman, C. (2004). Engineering ethics. Upper Saddle River, NJ: Prentice Hall.

Franklin, U. (1999). The real world of technology (Rev. ed.). Toronto, Ontario, Canada: House of Anansi Press.

Friere, P. (2000). Pedagogy of the oppressed. London, England: Continuum International Publishing.

Gorman, M., Mehalik, M., \& Werhane, P. H. (2000). Ethical and environmental challenges to engineering. Englewood Cliffs, NJ: Prentice Hall.

Graham, L. (1998). What have we learned about science and technology from the Russian experience? Stanford, CA: Stanford University Press.

Gramsci, A. (1971). Selections from the prison notebooks of Antonio Gramsci. Q. Hoare \& G. Nowell Smith (Eds.). New York, NY: International Publishers.

Herkert, J. R. (2005). Ways of thinking about and teaching ethical problem solving: Microethics and macroethics in engineering. Science and Engineering Ethics, 11, 373-385. 
Johnson, S., Lee, A., \& McGregor, H. (1996). Engineering as captive discourse. Society for Philosophy and technology, 1(3-4).

Jordan, W. (2011, June). Engineering ethics and justice: How do they relate? ASEE Annual Conference and Exposition, Conference Proceedings.

Kabo, J., \& Baillie, C. (2009). Seeing through the lens of social justice: A threshold for engineering. European Journal of Engineering Education, 34(4), 317-325.

Luegenbiehl, H. (2010). Ethical principles of engineers in a global environment. In I. Van de Poel \& D. E. Goldberg (Eds.), Philosophy and engineering: An emerging agenda (pp. 147-160). New York, NY: Springer.

Martin, M., \& Schinzinger, R. (2005). Ethics in engineering. New York, NY: McGraw-Hill.

National Society for Professional Engineers (July 2007). NSPE Code of Ethics. Retrieved from http://www.nspe.org/Ethics/CodeofEthics/index.html.

Nottingham County Council (July 2004). A framework for achieving equity and diversity in social services. Retrieved from http://cms.nottinghamshire.gov.uk/equitydiversity.pdf.

Rawls, J. (1971). A theory of justice. Cambridge, MA.: Harvard University Press.

Riley, D. (2008). Engineering and social justice. San Rafael, CA: Morgan \& Claypool. doi:10.2200/S00117ED1V01Y200805ETS007

Sen, A. (2009). The idea of justice. Cambridge, MA: Harvard University Press. 